\title{
THE NON-RECOGNITION OF ISLAMIC MARRIAGE AND DIVORCE
}

\author{
John McDermott*
}

\begin{abstract}
The general rule regarding the validity of foreign marriages followed by most US courts is that a marriage if validly performed is valid everywhere. But there are exceptions based on public policy. Thus, while a non-incestuous, monogamous marriage performed in a Muslim country between consenting adults would be recognized in the United States, a polygamous marriage most likely will not. Bigamy is a crime in all states, although the husband is rarely prosecuted unless there are other factors, e.g., spousal abuse or fraud. The U.S. Constitution's protection of an individual's religious rights might be asserted as a basis for allowing Muslim men to have more than one wife but it seems unlikely to succeed as the Supreme Court rejected a similar argument in a case involving a Mormon man who had several wives as permitted by his religion. However, several state supreme courts have recently held that a State cannot constitutionally ban same sex marriages; this article explores the possibility that similar bans on polygamous marriage might be
\end{abstract}

Professor, Layola Law School, Layola Marymount University, Los Angeles, California. 
held to be unconstitutional. The article also explores the difficulties encountered in attempting to have a US court give effect to a Ṭalāq divorce, especially where the Talāq is not confirmed by a court or other judicial body.

Keywords: U.S. Constitution, Freedom of Religion, Shari'ah, Polygamy, Taläq, Mahr and Nafaqah, Womens's Rights

\section{INTRODUCTION}

The United States Constitution, specifically, the First Amendment, ${ }^{1}$ is often said to separate church and state, but it would be incorrect - and unreasonable - to suggest that the Constitution could (or should) completely isolate the government from religious principles. Many U.S. laws are founded on Christian beliefs. While the United States remains a Christian country in the sense that a majority of the population adhere, to one degree or another, to a Christian religion, there continues to be a move toward greater secularism of laws dealing with what might be classified as "immoral behavior."

These Christian principles often come in conflict with principles of other religions. While each U.S. state generally respects another U.S. state's recognition of a valid marriage or divorce (unless there are strong policy facts indicating otherwise, such as nonage or incest), the issue of Islamic marriage and divorce poses a special problem because of the existence of fundamental and differing practices not found in Christian or American culture, most notably, polygamy and unilateral divorce. The growth of Islam in the United States has created new

\footnotetext{
$1 \quad$ U.S. Const. amend. I. ("Congress shall make no law respecting an establishment of religion, or prohibiting the free exercise thereof...”)

2 For example, adultery, which is condemned by most major religions, including both Christianity and Islam, was once a crime in some states, but is no longer. In addition, Catholic-Christian principles influenced the laws of many states, making divorce very difficult to obtain in certain, primarily East Coast, states. Today, most states have liberalized the law governing divorce, many adopting some form of "no fault" divorce.
} 
challenges to established Christian-based laws relating to marriage (conflict with polygamy) and divorce (talāq).

This paper explores these conflicts and examines the respect and recognition given to Islamic marriages and divorces in the United States.

\section{MARRIAGE AND DIVORCE LAWS IN THE UNITED STATES}

The authority to enact laws dealing with areas not specifically enumerated to Congress in Article I of the Constitution "are reserved to the States respectively, or to the people." ${ }^{3}$ Family law or domestic relations "has long been regarded as a virtually exclusive province of the States." Although the original jurisdiction of state and federal (national) courts overlap to a large degree, ${ }^{5}$ federal courts have historically refused to exercise their jurisdiction over marriage and divorce ${ }^{6}$ For that reason, most of the cases discussed in this paper are decisions of state courts rather than federal courts. ${ }^{7}$

In many countries, a couple wishing to be married simply registers the marriage with a government official - no ceremony, religious or civil is required for the couple to be legally married. If a formal ceremony is

$3 \quad$ U.S. Const. amend. X. ("The powers not delegated to the United States by the Constitution, nor prohibited by it to the States, are reserved to the States respectively, or to the people.") Sosna v. Illinois, 419 U.S. 393, 404 (1975). See also, Rose v. Rose, 481 U.S. 619, 625(1987).

5 The jurisdiction of the United States District Courts - the general national court of original jurisdiction - has, inter alia, jurisdiction over all civil suits with a value of US\$50,000 or more between the citizen (domicile) of one of the states and a citizen of one of the other fifty states or of a foreign country. 28 U.S.C.A $\$ 1332$

$6 \quad$ See, e.g., Barber v. Barber, 62 U.S. 582, 584 (1858). ("We disclaim altogether any jurisdiction in the courts of the United States upon the subject of divorce ....”)

$7 \quad$ The primary exception is those cases dealing with immigration and naturalization, issues exclusively within the jurisdiction of Congress, federal administrative agencies and federal courts. 
subsequently held it is to celebrate the marriage with friends and family or, for some, to be married in the "eyes of God."

However, in the United States, marriage involves two steps. The first seems similar to the "registration system" described above - the couple must go to a government office. However, they do not go there to be married but to obtain permission from the State to be married, i.e., a marriage license. ${ }^{8}$ The application requires some basic information about both of the individuals, including information about any prior marriages and information concerning the dissolution of any prior marriages. If an applicant indicated he or she has been married, he are she must establish that the prior marriage had been dissolved. The application must be signed "under the penalty of perjury."

But the couple is not yet married. They must appear before a person authorized by state law to perform a marriage ${ }^{10}$ and go through a ceremony which is culminated by the person performing the ceremony stating "by the power vested in my by the State of California, I now pronounce you man and wife.” After the ceremony has concluded, the

$8 \quad$ This can be a real problem for gay and lesbian couples who want to marry as state agencies historically have required the applicants to be a "man and a woman." Thus, many of the legal challenges to the ban on same sex marriages have been brought against the agency which issues marriage licenses. See, Goodridge v. Dep't of Pub. Health, 798 N.E.2d 941 (Mass. 2003), discussed infra, note 63.

9 A married Muslim man who wants to take a second or third wife is faced with this dilemma: If he admits he was married and that the marriage has not been dissolved he will not be able to obtain a license to marry. If he states that he has never been married or that the previous marriage has been dissolved, he has committed perjury - a criminal offense.

The laws of most states provide that any recognized member of the clergy (such as a Priest, Minister, Rabbi, Imam, Cantor, Ethical Culture Leader, etc.), or a judge, a court clerk, and justices of the peace have authority to perform a marriage. [In some states the member of the clergy must be first certified or licensed by the state to perform marriages]. California seems to allow anyone to perform a marriage if he or she has become a "Deputy Commissioner of Marriages." The authorization, which can be obtained on-line is only valid for one day, allowing the person to officiate at the wedding of family or friends on that one day. 
person who performed the marriage signs the marriage license attesting to the marriage. They are then legally married.

The validity of a marriage is governed, at least initially, by the law of the state in which the marriage is performed. Similarly, the validity of divorce is, at least initially, governed by the law of the state in which the divorce is granted. ${ }^{11}$ But the fact that a marriage is validly performed in one state or a divorce is granted by one state does not necessarily mean that either the marriage or divorce will be recognized in all other states. Disputes regarding the validity of an out-of-state marriage or divorce have been the subject of much litigation in the courts of each of the fifty states and, on rare occasion, they have reached the U.S. Supreme Court based on the "full faith and credit" clause of the Constitution. ${ }^{12}$ Unhampered by the full faith and credit clause - or by treaty obligations - the validity of marriages and divorces performed in other countries, while less frequently litigated, is governed by general principles of comity. ${ }^{13}$

\section{RECOGNITION OF OUT-OF-STATE MARRIAGES IN THE UNITED STATES}

The general rule in the United States has been that the law of the place of contracting is controlling. ${ }^{14}$ In accordance with this rule, it has generally been held that in the absence of statutes to the contrary, a marriage, if valid where celebrated, is valid everywhere; and that a marriage, if invalid where celebrated, is invalid everywhere. ${ }^{15}$ This rule

$11 \quad$ While state laws governing both marriage and divorce do vary to some degree, none authorizes either polygamy or a unilateral divorce.

12 U.S. Const., Article IV, Section 1. ("Full Faith and Credit shall be given in each State to the public Acts, Records, and judicial Proceedings of every other State.”) By its terms, this provision would not apply to a marriage or divorce performed outside the United States.

13 Black's Law Dictionary defines judicial comity as “[ $t$ ]he respect a court of one state or jurisdiction shows to another state or jurisdiction in giving effect to the other's laws and judicial decisions." Black's Law Dictionary 262 (7th ed. 1999).

$14 \quad 52$ Am. Jur. 2d Marriage § 74 (2008).

15 Restatement (Second) of Conflict of Laws $\S 283$ (1971), Validity of Marriage, is a restatement of today's general rule: 
is so well recognized in the United States that one court stated (some 90 years ago) that "the citation of authority in support of the rule is unnecessary." 16

Perhaps the most common basis for challenging the validity of an out-of-state marriage is where one or both of the parties are below the age allowed by local law. In such cases, most American courts have adopted the rule that the validity of a marriage is then governed by the law of the state (or, possibly, country) in which the parties were domiciled at the time of the marriage. ${ }^{17}$

A "conflict of laws" issue arises where a foreign marriage attacked on the ground of "nonage" (i.e., where one or both participants are below the minimum age for marriage under the law of the particular state) is valid under the law of the place of contracting but invalid under the law of the jurisdiction in which the parties to the marriage were domiciled at the time of the marriage, if it is (as is often the case) challenged in that state. The resolution of such issues has not been consistent in the courts of the fifty states. ${ }^{18}$ Some courts hold that the law of the domicile applies, thus creating an exception to the general rule under which a marriage if valid where solemnized is valid everywhere based on the public policy of the forum and domicile. However, other courts apply the law of the place of contracting even where it is contrary to the public policy of the domicile and forum.

An even more troublesome situation exists when the parties leave their state of domicile where they cannot marry and travel - sometimes only a few miles - to a state where their marriage is allowed. Where the

(1) The validity of a marriage will be determined by the local law of the state which, with respect to the particular issue, has the most significant relationship to the spouses and the marriage under the principles stated in $\S 6$.

(2) A marriage which satisfies the requirements of the state where the marriage was contracted will everywhere be recognized as valid unless it violates the strong public policy of another state which had the most significant relationship to the spouses and the marriage at the time of the marriage.

16 Thompson v. Thompson, 202 SW 175 (Tex. Civ. App. 1918).

17 52 Am. Jur. 2d Marriage § 74 (2008).

18 Marriage and divorce are matters of state - not national - concern, and each state can determine when to recognize such out-of-state marriages. 
parties marry in another jurisdiction solely to get around their domicile's marriage laws, the marriage may be annulled, as being repugnant to public policy. ${ }^{19}$ However, in the absence of statutes to the contrary, the mere fact that an extra-state marriage was contracted, for the specific purpose and with the specific intent of evading the age requirements of the domicile of the contracting parties, has been held not to render the marriage void.

One of the most commonly cited U.S. court decisions dealing with the recognition of an out-of-state marriage which was invalid - or even illegal - in the state of the couple's residence is In re Estate of May, ${ }^{20}$ a 1952 New York Supreme Court (not New York’s highest appellate court) decision.

The couple were residents of New York but could not marry in New York, not because one or both of them were underage or even because one of them was already married, but because the marriage was considered incestuous (a crime under New York law punishable by imprisonment for not more than ten years), ${ }^{21}$ as it was between a man and his niece. The couple went a short distance to the state of Rhode Island where they could legally be and were legally married. Being New York residents, they almost immediately returned home to New York.

$19 \quad$ E.H. Schopler, Conflict of laws as to validity of marriage attacked because of nonage, 71 A.L.R.2d 687 (1960). 280 A.D. 647 (N.Y. App. Div. 1952). Today, more than fifty years later, it is frequently cited in cases involving same sex marriages. In one such case, Langan v. St. Vincent's Hosp. of New York, 25 A.D.3d 90 (N.Y. App. Div. 2d Dep’t 2005), the surviving partner of a same-sex civil union under Vermont law a brought wrongful death action in New York against the hospital at which the now-deceased partner had received treatment. The lower court denied the hospital's motion to dismiss, and granted the surviving spouse's motion for partial summary judgment on question of standing. The Hospital appealed and a divided intermediate appellate court held that a surviving partner of a samesex civil union could not bring a wrongful death action, and that a statutory exclusion of partners in same-sex civil unions from classes of persons having standing to bring wrongful death suits did not offend the Equal Protection Clause of the U.S. Constitution. 
The court began its analysis by stating the general rule and its exceptions:

The general rule, too long and widely established to need much citation of authority, is that when contracted in another state or country, if valid there under the law of that place, it is valid everywhere. ... The only exceptions to this rule which obtain in our jurisdiction and which merit consideration in the instant case are: (1) cases coming within the inhibitions of natural law as it is recognized by countries adhering to the concepts of Christian culture and its antecedents, e.g., those which are polygamous or so incestuous in degree as to have been regarded with abhorrence since time immemorial, and (2) those prohibited by such of our positive laws as have extra-territorial force and bind the violator when he comes within or returns to our jurisdiction. ${ }^{22}$ (Emphasis added.)

The court then concluded that this incestuous marriage did not fall within either exception and therefore would be recognized in New York:

The blood relationship of an uncle and a niece is not sufficiently close to render their marital union so repugnant to our concept of the natural law as to bring it within the first class of exceptions aforestated. It was never so regarded either anciently or at common law. Indeed, it is still lawful in many jurisdictions in our country and abroad throughout Christendom. It was not interdicted by Levitical or Talmudical law and is presently sanctioned by the Jewish faith and doctrine. ${ }^{23}$

Next, then, is there anything in the prohibitory statute (Domestic Relations Law, § 5) which gives it

\footnotetext{
$22 \quad 280$ A.D. at 649.

23 Then why, in a country in which the Constitution requires the government to treat all bona fide religions equally, should a polygamous marriage sanctioned by the Qur’ān, not be similarly recognized?
} 
any extra-territorial force? Manifestly its highly criminal provisions as well as those of the Penal Law are not enforceable when the forbidden act is committed out of the state and he who thus acted comes or returns here. ${ }^{24}$

A discussion of this case would not be complete without discussion of some of its additional facts, as it seems quite likely that those facts influenced the court's decision to validate the marriage.

This case did not begin as a criminal prosecution under either New York's Penal Law or its Domestic Relations Law. Nor was it commenced by the niece, or her parents, to nullify the marriage. In fact, the couple lived together for more than thirty-two years - until the wife died - and raised six children together. Actually, it was one of the children who commenced the lawsuit to prevent her father from serving as the administrator of his deceased wife's estate on the grounds that, as a matter of law, he was "not a lawful surviving husband of deceased in that their intermarriage in the state of Rhode Island ... not be recognized (in New York).”25 Although the court did not so indicate, it must have thought it was a little late to be challenging this marriage.

\section{POLYGAMOUS MARRIAGES}

\section{U.S. POLICY ${ }^{26}$}

The general rule that a marriage valid where contracted will be recognized here is subject to a basic exception: Where a foreign marriage is offensive to a fundamental local policy, the local courts may refuse to give effect to it. ${ }^{27}$ Polygamous or incestuous marriages have been suggested as examples. ${ }^{28}$

\footnotetext{
$24 \quad$ Ibid.

$25 \quad$ Ibid, at 648.

26 The discussion of the "judicial history" of polygamy in the United States is based in large part on Lynn D. Wardle, Fundamental Principles of Family Law in Utah (BYU Academic Press, 2007) [hereinafter cited as "Wardle”] and used with Professor Wardle’s kind permission.

$27 \quad$ See Rest.2d, Conflict of Laws §283(2) and Comment k.

28 See Pearson v. Pearson, 51 Cal. 120, 125 (Cal. 1875).
} 
Polygamy has been strongly condemned in the United States for well over one hundred years. In Mormon Church v. United States, ${ }^{29}$ the Supreme Court described the spread of polygamy as "a return to barbarism.” The religious basis for the condemnation was unmistakable: "It is contrary to the spirit of Christianity and of the civilization which Christianity has produced in the Western world.” Sixty years later, Justice Douglas condemned polygamy as "a notorious example of promiscuity." 30

But a somewhat more enlightened member of the Court saw the issue quite differently:

[W]e are dealing here with polygyny [sic], one of the basic forms of marriage. Historically, its use has far exceeded that of any other form. It was quite common among ancient civilizations and was referred to many times by the writers of the Old Testament; even today it is to be found frequently among certain pagan and nonChristian peoples of the world. We must recognize then, that polygyny, like other forms of marriage, is basically a cultural institution rooted deeply in the religious beliefs and social mores of those societies in which it appears. It is equally true that the belief and mores of the dominant culture of the contemporary world condemn the practice as immoral and substitute monogamy in its place. To those beliefs and mores I subscribe, but that does not alter the fact that polygyny is a form of marriage built upon a set of social and moral principles. It must be recognized and treated as such. ${ }^{31}$

Unfortunately, the views of Justice Douglas seem to have prevailed. Polygamy is illegal in all fifty states.

\footnotetext{
$29 \quad$ 136 U.S.1(1889).

$30 \quad$ Cleveland v. United States, 329 U.S. 14, 19 (1946).

31 Ibid, at 26 (Murphy, J., dissenting).
} 


\section{POLYGAMY AND THE FIRST AMENDMENT}

In Reynolds v. United States, ${ }^{32}$ George Reynolds, a practicing member of the Church of Jesus Christ of Latter Day Saints (commonly referred to as "Mormons") was prosecuted in a Federal District Court in what was then the Territory of Utah for violating a federal law ${ }^{33}$ which made it a crime to enter into a bigamous marriage. ${ }^{34}$ He requested the trial judge to instruct the jury that it could find him not guilty "if they found that he had married in pursuance of and conformity with what he believed at the time to be a religious duty." The court refused to give the requested instruction and the jury found him guilty as charged; he was sentenced to two years in prison and ordered to pay a $\$ 500$ fine. The Territorial Supreme Court affirmed the judgment and the United States Supreme Court upheld the conviction..$^{35}$

In its decision, the Court acknowledged that Congress cannot pass a law which shall prohibit the free exercise of religion as "the first amendment to the Constitution expressly forbids such legislation.” But, the Court asked rhetorically, "What is the religious freedom which has been guaranteed.” The answer it gave was that "Congress was deprived of all legislative power over mere opinion, but was left free to reach actions which were in violation of social duties or subversive of good order." And it had no difficulty finding that polygamy was the type of "action" which it could constitutionally prohibit:

Polygamy has always been odious among the northern and western nations of Europe, and, until the establishment of the Mormon Church, was almost exclusively a feature of the life of Asiatic and of African people. At common law, the second marriage was

98 U.S. 145(1878).

Because Utah had not yet become a state, federal law applied to all activities within the territory.

The punishment was a fine of not more than $\$ 500$ and imprisonment for a term of not more than five years.

Reynolds eventually served 18 months in prison and was viewed by all members of the (Mormon) Church of Jesus Christ of Latter-day Saints as a "living martyr to the cause of Zion." His fine was paid by the donations of Sunday school children. Wardle, supra, note 26 at 22.
} 
always void and from the earliest history of England polygamy has been treated as an offence against society. ... [I]t may safely be said there never has been a time in any State of the Union when polygamy has not been an offence against society, cognizable by the civil courts and punishable with more or less severity. In the face of all this evidence, it is impossible to believe that the constitutional guaranty of religious freedom was intended to prohibit legislation in respect to this most important feature of social life.

[T] here cannot be a doubt that, unless restricted by some form of constitution, it is within the legitimate scope of the power of every civil government to determine whether polygamy or monogamy shall be the law of social life under its dominion.

This being so, the only question which remains is, whether those who make polygamy a part of their religion are excepted from the operation of the statute. If they are, then those who do not make polygamy a part of their religious belief may be found guilty and punished, while those who do, must be acquitted and go free. This would be introducing a new element into criminal law. Laws are made for the government of actions, and while they cannot interfere with mere religious belief and opinions, they may with practices.

When appeals to courts and lawmakers were unsuccessful, the prophet-leader of the Church issued an Official Declaration in 1890 prohibiting further plural marriages and excommunicating from the Church those who subsequently entered into polygamous marriages. But some members of the Church who were determined to continue to practice polygamy formed various "fundamentalist" churches, which still exist in several western states where polygamy is openly practiced. However, there have be relatively few prosecution of persons practicing polygamy unless some incident occurs that raises public concern, such as spousal abuse, underage marriage or even worse, incest. ${ }^{36}$

$36 \quad$ In 2003, responding to scandals involving young girls taken as polygamous brides, the Utah legislature passed legislation making it a 
In In re Estate of May, the New York court was willing to recognize a foreign - out-of-state - marriage that was valid where performed but incestuous in New York. Will it also recognize a foreign marriage that was valid where performed but bigamous in New York? Apparently not!

In People v. Ezeonu,${ }^{37}$ the defendant, a Nigerian national, was charged with second-degree rape ${ }^{38}$ and sought to assert as a defense that the victim was his "second" or "junior" wife under Nigerian law. The decision may have been affected by the fact that the complainant was thirteen years old at the time of the alleged crime. ${ }^{39}$ In addition, it does not appear that she consented to the marriage, assuming that she was old enough to have legally done so. ${ }^{40}$ Defendant acknowledged that he already was legally married under both New York and Nigerian law at the time he entered into the purported second marriage, but asserted that the laws and tribal customs of Nigeria allowed one man to have multiple wives.

The court held that, even were defendant's "marriage" to the complainant conducted in accordance with Nigerian law and custom, the marriage was null and void in New York and that, as a matter of law, he could not invoke the "marital exemption" to the charge of second degree rape. ${ }^{41}$

second-degree felony punishable by ten years in prison to commit polygamy with a person under eighteen. Utah Code Ann. § 76-7-101.5 (2008).

$37 \quad 588$ N.Y.S.2d 116 (N.Y. Sup. Ct. 1992).

38 Second Degree Rape, often referred to as “statutory rape," provides that "a person is guilty of rape in the second degree when being eighteen years old or more, he or she engages in sexual intercourse with another person less than fifteen years old.” New York Penal Law Section 130.30(A)(1).

39 It seems unlikely that any U.S. court would find that foreign law protected a person from a crime against a child. The record indicated that she was given to him by her parents in Nigeria, pursuant to the laws and tribal customs of that country.

The defendant pled what was commonly referred to as the "marital rape exemption" which was based on the common law doctrine that marriage fused two individuals into a single legal entity. In simple terms, as the husband and wife were "one," he could not be charged with raping himself. Most States have abolished the defense - the New York Court of Appeals held it to be unconstitutional in People v. Liberta, 473 N.Y.S.2d 636 (App. Div. 1984). 
The court acknowledged the general rule in New York, that a marriage is recognized in New York if it is valid where consummated, but pointed out that the general rule does not apply where recognition of a marriage is repugnant to public policy.

Unlike the court in In re Estate of May, the court found that a polygamous marriage was repugnant to public policy as evidenced by Section 6 of the Domestic Relations Law, which provides that "A marriage is absolutely void if contracted by a person whose husband or wife by a former marriage is living, (unless it had been lawfully annulled or dissolved)." The court added that in New York a bigamous marriage is not "voidable" but "absolutely void" and that bigamy is a crime in the State of New York. ${ }^{42}$

The decision was consistent with several other New York cases involving bigamous and polygamous marriages:

It has been held that when this state is called upon to recognize either an incestuous or bigamous marriage, it will assert its strong public policy of condemnation thereof and refuse recognition even if that marriage was valid where consummated. Consequently, a polygamous marriage legally consummated in a foreign country will be held invalid in New York. ${ }^{43}$

Another New York state court reached the same conclusion in a civil matter. ${ }^{44}$ There, the plaintiff alleged that she was married to the defendant in Nigeria and was one of defendant's twenty-five wives. The court refused to recognize the alleged marriage, holding that "bigamous or polygamous marriages even if legal where contracted are not considered valid as a matter of law and public policy." 45

However, where the objectionable relationship has been terminated by death, rights of succession often present no problem of

\footnotetext{
$42 \quad$ See NY Penal Law $\S 255.15$.

$43 \quad$ See Matter of Bronislawa K. v Tadeusz K., 90 Misc 2d 183, 185, citing Matter of May, 305 NY 486.

$44 \quad$ Uboh-Abiola v Abiola, NYLJ, June 12, 1992, at 22, col 1 [Sup Ct, NY County].

45 Ibid, at 22, col 1, citing Matter of Satya Pal Sood v Apps, 208 Misc 819 [Sup Ct, Onondaga County], affd 1 AD2d 939.
} 
public policy and may be enforced. In In re Dalip Singh Bir's Estate, ${ }^{46}$ a civil case more like In re Estate of May than People v. Ezeonu, the California District Court of Appeals recognized the standing of both wives as heirs of their deceased husband's estate.

Dalip Singh Bir, a native of India, died intestate in California. Two women, Harnam Kaur and Jiwi, both residents of India, joined in a petition to determine heirship, alleging that at the time of the death of the deceased they were both legally wedded wives of the deceased, having lawfully married said deceased in the Punjab over 50 years ago while all three were domiciled in Punjab "according to the law and manner of the Jat community, in which province and community said marriages are lawful and valid." 47

Both claimed to be entitled to share equally in his "community property." However, the trial court concluded that under the laws of California and the public policy thereof, only the first wife of decedent could be recognized as his legal widow.

The widows disagreed, citing section 63 of the California Civil Code which reads:

"All marriages contracted without this state, which would be valid by the laws of the country in which the same were contracted are valid in this state."

Since the marriages were allegedly performed at a time when India was governed by English law, the appellate court began its analysis by examining English law and that other Commonwealth countries, namely Canada, to determine if the polygamous marriages would have been valid under English law, but found "a singular absence of direct authority on the question in the English cases, the decisions of American Courts or of Courts in other parts of the British Empire would presumably in a matter of this kind have a considerable persuasive authority in so far as they are decisions of Courts applying a law which is either based on English law or which, like English law, does not allow of polygamy."48

\footnotetext{
$46 \quad 83$ Cal. App. 2d 256 (Cal. App. 1948).

$47 \quad$ Ibid.

$48 \quad$ Ibid, at 258.
} 
The court noted that polygamous marriages among Native Americans had frequently been held valid, referring to Ortley v. Ross, ${ }^{49}$ where the court acknowledged the unique status of Native Americans in the United States:

Now, it is contended by appellants that, as the alleged marriage between the father and mother of the plaintiff was polygamous, it was neither valid in the state of Minnesota, where the parties then resided, nor in the state of Nebraska to which they subsequently removed. This contention would be well founded if this marriage had taken place between citizens of the United States in any state of the Union. But a different rule prevails with reference to the marriages of Indians, who are members of a tribe recognized and treated with as such by the United States government; for it has always been the policy of the general government to permit the Indian tribes as such to regulate their own domestic affairs, and to control the intercourse between the sexes by their own customs and usages.

The court also considered Succession of Caballero v. The Executor et al. ${ }^{50}$ In that case, the deceased lived with a black woman in Louisiana and had several children by her. Prior to his death he married the black woman in Havana, Cuba, where marriages between whites and blacks were valid, and thus legitimated the children. From Cuba he moved with his family to Spain where his children remained. Upon Caballero's death a dispute arose as to inheritance, the executor of decedent's will claiming the children were illegitimate since Louisiana declared all marriages between whites and blacks to be void. The court held in favor of a child claimant as to her right to succeed to her father's estate, notwithstanding the very strong public policy in Louisiana prohibiting miscegenation:

We understand the rule to be well settled that marriages valid by the laws of the country where they are entered

$\begin{array}{ll}49 & \text { 110 N.W. } 982 \text { (Neb. 1907). } \\ 50 & \text { 24 Louisiana Annual Reports } 573 .\end{array}$ 
into, are held valid in any other country to which the parties may remove, unless there exists, from reasons of public policy, in the country to which they remove, some impediment by the laws of that country, or that such marriages are in derogation of good morals. In such exceptional cases comity could not be invoked to recognize their validity. How stands the matter in regard to the rights of Mrs. Conte, the plaintiff in this case? Here we may notice that this person, after her parents removed from Louisiana to Spain, never returned to Louisiana to live, and that she is a subject of the government of Spain. At the time of her legitimation by the marriage of her parents, marriage between white persons and free persons of color was prohibited by our law. The Louisiana law would not have recognized as valid in Louisiana the marriage of Caballero in Havana. ... Thus far would our law have extended and had effect when Caballero returned to Louisiana, but no further. Its edict, so far as it bore upon his marriage, was of local and limited effect. It existed for a purpose local and special in this country. That purpose could not have been more effectually carried out by withholding from persons abroad, legitimate by the laws of the country where they lived, the right of inheriting property in this State. ... The policy of this State had no broader extent, because there was no reason why it should have. (Italics added.)

The Court of Appeals in Bir concluded the trial court's decision was improperly influenced by the rule of "public policy," as, in its view, "that rule ... would apply only if decedent had attempted to cohabit with his two wives in California." "Public policy" would not be affected by dividing the money equally between the two wives, particularly since there is no contest between them and they are the only interested parties. ${ }^{51}$ The law in Bir is still valid as applied to polygamous marriages; however, it seems to be a stand-alone case and has not been applied in subsequent 
cases. It is a rare and narrow exception to the "public policy" exception. As explained in Wong v. Tenneco, ${ }^{52}$ the "public policy" exception precludes application of a foreign state's law where to do so would violate California's public policy. The standard, however, is not simply that the law is contrary to our public policy, but that it is so offensive to our public policy as to be "prejudicial to recognized standards of morality and to the general interests of the citizens ...."53 Moreover, even where it is agreed that a foreign law offends public policy, it may still be applied in a limited context where the potential harm is minimal. ${ }^{54}$

Thus, as in In re Estate of May, U.S. courts seem willing to recognize the economic consequences of polygamy, if not the matrimonial effects.

\section{IMMIGRATION, NATURALIZATION \& DEPORTATION BASED ON POLYGAMOUS MARRIAGES}

\section{U.S. IMMIGRATION POLICY}

On the ground that polygamy is illegal under American law, the Immigration and Naturalization Service, now a part of the Department of Homeland Security, will not give a Muslim man with more than one wife ${ }^{55}$ an immigrant visa and will deport him if it subsequently discovers

\footnotetext{
$52 \quad$ 39 Cal. 3d 126, 135 (Cal. 1985).

53 Biewend v. Biewend, 17 Cal.2d 108, 113 (1941).

54 See, e.g., Estate of Bir, 83 Cal. App. 2d 256 (1948) (in the context of intestate succession only, India's law permitting polygamy will be applied under principles of comity).

55 "A spouse is a legally wedded husband or wife. Merely living together does not qualify a marriage for immigration. Common-law spouses may qualify as spouses for immigration, but only if the laws of the country where the common-law marriage occurs recognizes commonlaw marriages and grants them all the same rights and obligations as a traditional marriage. In cases of polygamy, only the first spouse may qualify as a spouse for immigration.” U.S. Department of State, Immigrant Visa for a Spouse (IR1 or CR1) (visited July 22, 2008), at http://ravel.state.gov/visa/immigrants/types/types_2991.html.
} 
that he has (or once had) more than one wife who he has not validly divorced. ${ }^{56}$

In Matter of $H,{ }^{57}$ a polygamous marriage, which was valid in Jordan where performed, was not recognized as a valid marriage for immigration purposes and would not support a visa petition for the husband because "the marriage was repugnant to United States public policy." The second wife was a native-born citizen of the United States. She and her husband, both Muslims, were married in Jordan. At the time, her husband was married to another woman - polygamous marriages being allowed in Jordan. Four months later, he divorced his first wife. Notwithstanding the fact that the first marriage was dissolved subsequent to the second polygamous marriage and therefore when the petition was sought, the husband only had one wife, the petition was denied.

Matter of $H$ seems to be the "controlling law" for the U.S. Immigration \& Nationalization Service (INS) ${ }^{58}$ a United States citizen spouse will not be able to file an immediate relative visa petition for her husband if all previous marriages had not been legally terminated at the time of the marriage to the United States citizen spouse.

This policy only extends to immigrant visas. Muslim men with more than one wife at home may be given non-immigrant visas but, at least in theory, may only bring one wife with them to the United States since they will not be "practicing polygamy" in the United States. ${ }^{59}$ But it seems that

$56 \quad$ "U.S. law does not allow polygamy (having more than one husband or wife at the same time). If you were married before, you and your spouse must both show that you ended (terminated) all previous marriages before your current marriage. The death and divorce documents that show termination of marriages must be legal and verifiable in the country that issued them. Divorces must be final. In cases of legal marriage to two or more spouses at the same time, or marriages overlapping for a period of time, you can file only for your first spouse.” Ibid. But United States law, which is national law, does not regulate marriage and divorce; it is the laws of the fifty states which prohibit polygamy.

579 I. \& N. Dec. 640, (BIA 1962).

58 The INS is now part of the US Department of Homeland Security.

Section 212(a)(10)) of the Immigration and Nationality Act: "Any immigrant who is coming to the United States to practice polygamy is inadmissible." [Emphasis added] Notwithstanding this provision, there is some indication that Consular Officers exercise the discretion to give non-immigrant/temporary visas to a second wife. 
this prohibition is easily circumvented. Muslim men with multiple wives can obtain a non-immigrant visa to legally enter the United States with their first wife, and then have relatives sponsor the other wives, or arrange for the other wives to get temporary visas, so they can all live together in the United States. Since polygamy involving consenting adult women is rarely prosecuted, ${ }^{60}$ this arrangement is surprisingly common. Therefore, while polygamy is illegal in the United States, forms of it are still practiced overtly, pursuant to religious traditions, or covertly, by the maintenance of two or more family units. ${ }^{61}$

\section{RECENT DEVELOPMENTS}

While polygamy has not been a major controversy in the United States - with the exception of the recent episode when a state trial upheld the removal of more than 400 children from a polygamous "compound" in Texas ${ }^{62}$ - marriage between couples of the same sex has been. Not surprisingly, this controversy has reached the courts and has been the subject of national and state legislation. While not directly affecting polygamous marriages, they may do so indirectly and perhaps inadvertently.

60 Jason D. Berkowitz, Beneath the Veil of Mormonism: Uncovering the Truth About Polygamy in the United States and Canada, 38 U. Miami Inter-Am. L. Rev. 615, 627 (2006-2007) (discussing the hesitancy of government officials to fully enforce polygamy statutes, despite the dismissal of every case challenging the constitutionality of such laws). Michele Alexandre, Lessons from Islamic Polygamy: A Case for Expanding the American Concept of Surviving Spouse So As to Include De Facto Polygamous Spouses, 64 Wash \& Lee L. Rev. 1461 (2007).

The Texas Department of Family and Protective Services had removed 468 children from the Fundamentalist Church of Jesus Christ of Latter Day Saints (FLDS) compound in Eldorado, Texas because of the sect's alleged practice of marrying off and impregnating underage girls. However, a Texas appellate court found no evidence of an "immediate" or "urgent" danger - which Texas law required - with respect to every child, and eventually ordered the children returned to their mothers. 
The highest courts of Massachusetts, ${ }^{63}$ California, ${ }^{64}$ Connecticut ${ }^{65}$ and Iowa ${ }^{66}$ have held that the respective states could not prohibit same sex marriages. In Goodridge v. Department of Public Health, the Supreme Judicial Court of Massachusetts rejected the argument that long established limitations of the right to marry can only be changed by the state legislature:

For decades, indeed centuries, in much of this country (including Massachusetts) no lawful marriage was possible between white and black Americans. That long history availed not when the Supreme Court of California held in 1948 that a legislative prohibition against interracial marriage violated the due process and equality guarantees of the Fourteenth Amendment, Perez v. Sharp, 32 Cal.2d 711, 728 (1948), or when, nineteen years later, the United States Supreme Court also held that a statutory bar to interracial marriage violated the Fourteenth Amendment, Loving v. Virginia, 388 U.S. 1 (1967). As both Perez and Loving make clear, the right to marry means little if it does not include the right to marry the person of one's choice, subject to appropriate government restrictions in the interests of public health, safety, and welfare. ${ }^{67}$

Turning to the Massachusetts Constitution, the Court emphasized that: ${ }^{68}$

The Massachusetts Constitution protects matters of personal liberty against government incursion as zealously, and often more so, than does the Federal Constitution, even where both Constitutions employ

\footnotetext{
$63 \quad$ Goodridge v. Dep't of Pub. Health, 798 N.E.2d 941 (Mass. 2003).

$64 \quad$ In re Marriage Cases, 43 Cal. 4th 757 (Cal. 2008). Voters subsequently narrowly put in a place a constitutional amendment to define marriage as only between a man and a woman.

65 Kerrigan v. Comm'r of Pub. Health, 289 Conn. 135 (Conn. 2008).

66 Varnum v. Brien, 2009 WL 874044 (Iowa 2009).

$67 \quad 798$ N.E.2d at 958 .

$68 \quad$ Ibid, at 959.
} 
essentially the same language. That the Massachusetts Constitution is in some instances more protective of individual liberty interests than is the Federal Constitution is not surprising. Fundamental to the vigor of our Federal system of government is that "state courts are absolutely free to interpret state constitutional provisions to accord greater protection to individual rights than do similar provisions of the United States Constitution." 69

Applying the Massachusetts Constitution to the ban on gay marriages, the Court found the ban unconstitutional:

The individual liberty and equality safeguards of the Massachusetts Constitution protect both "freedom from" unwarranted government intrusion into protected spheres of life and "freedom to" partake in benefits created by the State for the common good. Both freedoms are involved here. Whether and whom to marry, how to express sexual intimacy, and whether and how to establish a family - these are among the most basic of every individual's liberty and due process rights. ... The liberty interest in choosing whether and whom to marry would be hollow if the [State] could, without sufficient justification, foreclose an individual from freely choosing the person with whom to share an exclusive commitment in the unique institution of civil marriage. ${ }^{70}$

While this decision focuses on the choice of "the person with whom to share ... in the unique institution of civil marriage," the broader reference to the basic right to determine "whom to marry" could well be extended to the right of three or more adults to chose a polygamous marriage.

The legislative response to the same-sex marriage controversy has generally been hostile. Although some states (for example, Vermont) have or are considering laws which, while banning same sex marriages,

\footnotetext{
$69 \quad$ Ariz. v. Evans, 514 U.S. 1, 6 (U.S. 1995).

$70 \quad 798$ N.E.2d 941 at 959.
} 
provide equivalent rights to gay and lesbian couples who become "domestic partners," most laws prohibit gay marriage by defining marriage as between $a$ man and $a$ woman. (Emphasis added.) While the intention is clearly to prevent marriages between two men or two women, the language of such laws would seem to also ban the marriage of two of more women and $a$ man. To prevent state courts from holding - as four State Supreme Courts have done - that the state constitution would make such a law unconstitutional, the opponents of gay marriage are attempting to amend the state constitutions to declare that a marriage is a between $a$ man and $a$ woman.

Congress has enacted the Defense of Marriage Act (hereinafter "DOMA") which provides, in part:

In determining the meaning of any Act of Congress, or of any ruling, regulation, or interpretation of the various administrative bureaus and agencies of the United States, the word "marriage" means only a legal union between one man and one woman as husband and wife, and the word "spouse" refers only to a person of the opposite sex who is a husband or a wife. (Emphasis added.)

Again, while clearly aimed at gay marriages, the language seems to mean that a polygamous marriage - a legal union between one man and two or more women - cannot be recognized as a valid marriage by any federal agency. ${ }^{71}$

$71 \quad$ DOMA also attempts to limit the extent that the Full faith and Credit Clause of the Constitution requires a state to recognize a marriage validly performed in another state:

No State ... shall be required to give effect to any public act, record, or judicial proceeding of any other State ... respecting a relationship between persons of the same sex that is treated as a marriage under the laws of such other State ... or a right or claim arising from such relationship.

The language of this provision would clearly have no effect on the recognition to be given to polygamous marriages. 


\section{DIVORCE IN THE UNITED STATES}

While a priest, rabbi or other cleric can create a marriage, only a court of law can dissolve it. A person cannot divorce his or her spouse simply by saying "I divorce you" whether it is in private or before a judicial officer. State law determines what conduct, if proven, will justify the dissolution of the marriage. Historically, most states required some degree of "fault" of one or both parties before a divorce could be granted such as:

(1) Impotency; (2) Adultery; (3) Extreme cruelty; (4) Willful desertion for five (5) years of either of the parties, or for willful desertion for a shorter period of time in the discretion of the court; (5) Continued drunkenness; (6) The habitual, excessive, and intemperate use of opium, morphine, or chloral; (7) Neglect and refusal, for the period of at least one year next before the filing of the petition, on the part of the husband to provide necessaries for the subsistence of his wife, the husband being of sufficient ability; and (8) Any other gross misbehavior and wickedness, in either of the parties, repugnant to and in violation of the marriage covenant. ${ }^{72}$

Today, many states also grant "no fault" divorces when, "irreconcilable differences which have caused the breakdown of the marriage."73

It may be important to note that either spouse - husband or wife - can obtain a divorce on the same grounds.

Procedurally, the spouse seeking the divorce files a law suit in a state court ${ }^{74}$ setting forth the ground for divorce. The other spouse must,

72 General Laws of Rhode Island - Title 15, Chapters 15-5-2 15-5-3, 15-53.11505-5.

$73 \quad$ Ibid.

$74 \quad$ Under U.S. law, the state in which the petitioner is domiciled when the suit is filed has "jurisdiction" over the "marital status" and can render a decree dissolving the marriage. See, Williams v. State of North Carolina, 325 U.S. 226 (1945) and Sherif v. Sherif discussed infra, note 
of course, be notified of the suit and can, if he or she wishes, contest the basis for the divorce.

\section{RECOGNITION OF OUT-OF-STATE DIVORCES IN THE UNITED STATES}

To render a valid judgment - one that can be enforced domestically and, possibly, in other countries - a court must have "subject matter jurisdiction," the authority to hear and decide the specific type of case, and "personal jurisdiction" over the parties who are to be bound by the court's judgment.

Subject matter jurisdiction is generally defined by state statute. Some courts, like special family court, have exclusive jurisdiction to grant divorces, while in other states, the courts of general jurisdiction can grant divorces.

Personal jurisdiction can be based on consent or waiver, on service with process within the jurisdiction, or by "minimum contacts" with the state.

Under U.S. law, a court which is asked to enforce a judgment can-unless the parties have previously litigated the jurisdictional issues or issues-makes its own determination of the original court's subject matter and personal jurisdiction. If it finds either to be defective, it generally will not recognize or enforce the original judgment or decree.

While these basic principles apply to divorce and custody matters, there is a fundamental difference: the court which grants the divorce need not have personal jurisdiction over both spouses. The legal fiction employed is that each spouse is clothed with the status of a married person and a court need only have personal jurisdiction over one of them to terminate the status of being married. But mere presence in the state or country or consent to the court's jurisdiction is insufficient to establish "divorce jurisdiction" - jurisdiction only exists in states where one of the parties is domiciled. The absence of such domicile will render the divorce void and unenforceable. This doctrine applies with equal force for divorces

75. It cannot, however, without personal jurisdiction over the defendant (or the defendant's consent) resolve financial or custody disputes. See, for example, Sherrer v. Sherrer, 334 US 342 (1948). 
granted in one of the fifty U.S. states, as well as those grated in foreign countries.

Sherif $v$. Sherif $f^{75}$ is a classic example of the application of the general rule regarding the recognition of a foreign divorce. Husband and wife were Egyptian nationals; both were born in Egypt, lived there and were married there. The marriage contract had a provision for the wife's support in the event of divorce, presumably in conformity with the customs of that country. They came to the United States in 1971 but returned to Egypt in 1973 and were divorced there. The wife conceded that the divorce was valid in Egypt so the issue before the court was whether it would be recognized in New York "as a matter of "comity." "76

Although the court did not "approve" of Egyptian divorce law, it noted that "the Court's approval or benediction of this divorce is not necessary to validate it" and concluded that "the facts of this case do not make it offensive to the public policy of this State to accord it recognition."77 The court concluded:

The case at bar does not involve a 'mail order' divorce issued by a country having no relationship to the parties' marital status. The divorce [possibly a traditional talāq divorce] was rather granted by a country wherein the parties were domiciled at all crucial points in their marital history. It is not shocking to 'the conscience to conclude that people who marry under a certain set of laws may expect to be bound only so long as that set of laws required it. ${ }^{98}$

\section{LACK OF JURISDICTION OF THE DIVORCE COURT}

Generally, the invalidity of a divorce due to the absence of jurisdiction by the rendering court impacts one or both of the parents.

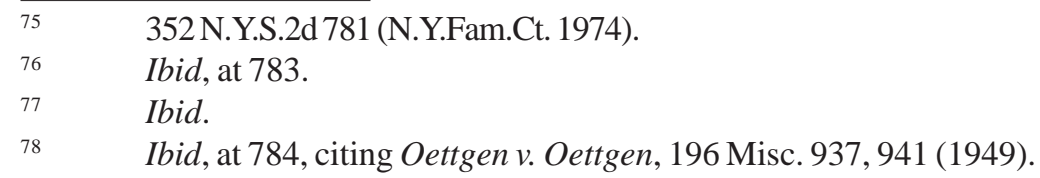


However, in Jahed v. Acri, ${ }^{79}$ it affected the right of their son to remain in the United States.

The facts, simply stated, are that Jahed was born in Afghanistan in May 1979 as his parents were both natives of Afghanistan. In 1984, fearing Communist forces in Afghanistan, the family fled to Pakistan, where they applied for refugee status at the United States embassy. The family relocated to the United States and received an adjusted status as aliens admitted for lawful permanent residence.

In December 1991, both parents went to Pakistan to choose a wife for one of Jahed's brothers. They had a disagreement over the choice of the wife, one that was so serious that it resulted in Jahed's father divorcing his mother in accordance with Islamic law. ${ }^{80}$ The father was given custody of Jahed. On May 18, 1995, before Jahed's eighteenth birthday, his father became a naturalized United States citizen.

A few years later, Jahed was convicted of a felony in a Virginia court and the Immigration and Naturalization Service (INS) ${ }^{81}$ subsequently began removal proceedings asserting that Jahed was "an alien" removable from the United States based on his Virginia conviction. Jahed asserted that he was not an alien - and therefore not deportable - as he had acquired derivative citizenship in 1995 when his father became a naturalized citizen.

The applicable law at the time provided that a child born outside of the United States of alien parents would become a citizen of the United States upon fulfillment of the following conditions:

The naturalization of the parent having legal custody of the child when there has been a legal separation of the parents ... if such naturalization takes place while such child is under the age of eighteen years; and such child

49 468 F.3d 230 (4th Cir. 2006).

80 While the official report of the decision does not indicate the type of divorce the father obtained, since it was based on his wife's "insubordination," there seem to be a good chance that it was a unilateral (talāq) divorce. Some U.S. courts have refused to recognize such divorces.

81 The INS is now part of the Department of Homeland Security. See Homeland Security Act of 2002, Pub.L. No. 107-296, § 441, 116 Stat. 2135, 2192. 
is residing in the United States pursuant to a lawful admission for permanent residence at the time of the naturalization of ... the parent naturalized under above clause. $^{82}$

The Immigration Law Judge determined that Jahed was not a citizen of the United States but instead a citizen of Afghanistan on the basis that Jahed's parents' Islamic divorce was not valid for purposes of United States immigration law, and thus, Jahed could not automatically acquire derivative citizenship. ${ }^{83}$

The case eventually reached the United States Court of Appeals for the Fourth Circuit. The court first acknowledged "the general rule that a foreign decree of divorce valid where rendered is valid everywhere and will be recognized ... under the principle of comity, provided that recognition would not contravene public policy." ${ }^{84}$ But it emphasized a fundamental exception to the general rule: the "foreign court must have jurisdiction to render a valid decree, ... and a divorce obtained in a foreign country will not normally be recognized as valid if neither of the spouses had a domicile in that country...." 85

In rendering its decision, the court relied on a previous INS case, Matter of $M a,{ }^{86}$ which decided the validity of a Korean divorce of two Korean citizens who were not domiciled in Korea. The Board of Immigration Appeals (the BIA) ${ }^{87}$ found that although the divorce was valid where rendered, it was nonetheless "invalid in the United States for purposes of the immigration law." ${ }^{88}$ The court considered the following

\footnotetext{
$82 \quad$ 8U.S.C. $\$ 1432(a)$.

$83 \quad$ Jahed v. Acri, 468 F.3d 230, 232 (4th Cir. 2006). administrative body for interpreting and applying immigration laws. It does not conduct courtroom proceedings - it decides appeals by conducting a "paper review" of cases, although on rare occasions, however, the Board does hear oral arguments of appealed cases, predominately at headquarters. The Board has nationwide jurisdiction to hear appeals from decisions rendered by Immigration Judges which are then subject to judicial review in the Federal courts. 
factors in reaching that conclusion: (1) whether the parties were divorced in the same jurisdiction in which they were married; (2) whether they lived in the divorcing jurisdiction as husband and wife; (3) whether they were present in the jurisdiction at the time of the divorce or otherwise consented to personal jurisdiction; and (4) whether they were citizens of the country granting the divorce. ${ }^{89}$ The BIA found that both parties were married and divorced in Korea, were citizens of Korea, and consented to the Korean divorce. Nonetheless, the BIA found the divorce invalid because they were "never domiciled together as husband and wife in Korea." $" 90$

The court concluded that "this analysis dooms Jahed's claim" pointing out that Jahed's parents were married in Afghanistan, but divorced in Pakistan. ${ }^{91}$ Although they both consented to the divorce in Pakistan and were physically present for the divorce, they were not citizens of Pakistan at the time, or at any time before or thereafter, and most importantly had never established domicile ${ }^{92}$ in Pakistan. Since the divorce was not recognizable by the INS, neither was the custody order and therefore Jahed's father was not "the parent having legal custody of the child when there has been a legal separation of the parents" as required by 8 USC $\S 1432(a)$.

Although Jahed's parents had traveled to Pakistan before coming to the United States in 1984, they did so for the purposes of fleeing the war in Afghanistan and requesting asylum at the United States embassy. When they went back to Pakistan in 1991, they did so for the purpose of finding a wife for their son, with the apparent intention of returning to the United States when they had found a suitable bride. The court concluded:

They never traveled to Pakistan with any intent to make a home and remain there permanently. Rather, they

\footnotetext{
$89 \quad$ Ibid, at 71.

$90 \quad$ Ibid.

$91 \quad$ Jahed v. Acri, 468 F.3d 230, 235 (4th Cir. 2006).

92 Domicile is defined in the United States as "a person's true, fixed, principal and permanent home.” Black’s Law Dictionary 523 (8th ed.2004). To change domiciles, a person must intend to make the new place her home. See, e.g., Ecker v. Atl. Ref. Co., 222 F.2d 618, 621 (4th Cir.1955) ("For the establishment of domicile the intention must be not merely to live in the place but to make a home there”).
} 
traveled to Pakistan to undertake specific purposes, and Pakistan was therefore - for purposes of United States law - powerless to enter a divorce over the two Afghan nationals who were domiciled in the Commonwealth of Virginia. ${ }^{93}$

In short, their Pakistani divorce was utterly lacking in extraterritorial validity. ${ }^{94}$

Because the court determined that Jahed was an alien and that there was no dispute over his prior conviction, it lacked the authority to review the BIA's final order of removal. ${ }^{95}$

\section{APPLYING THE “NEW LEARNING” TO RESOLVE ISSUES OF MARRIAGE AND DIVORCE}

Historically, the generally accepted rule governing the recognition of both foreign marriages and foreign divorces was to apply the law of the place where the marriage or divorce took place. This relatively rigid approach is a vestige of the territorial "vested rights" approach to choice of law developed by Justice Story and adopted by Professor Beale, ${ }^{96}$ which looked at a single event and applied the law of the place where that event occurred. Hence the validity of a marriage was governed by the law of the place where the marriage took place and the validity of a divorce was determined by the law of the place where the divorce degree was rendered.

\footnotetext{
93 $\quad 468$ F.3d at 236.

$94 \quad$ The court further noted the evidence suggests that Jahed's parents did not view their Islamic divorce as a valid divorce for purposes of United States immigration law. In fact, when Jahed's mother was naturalized in 2000, and in her May 27, 2000, interview with the INS, she stated that she was still married and living at the same address as the father.

95 Accord, Soliman v. Gonzales, 419 F.3d 276, 280 (4th Cir.2005) (holding that we must dismiss a petition for review of a person who is removable by reason of having committed a criminal offense if we conclude that the petitioner is (1) an alien and (2) has been convicted of an aggravated felony).

962 J. Beale, A Treatise on the Conflict of Laws § 378.2 (1935).
} 
Although this approach has been replaced in most other types of cases, especially in negligence and other torts cases where the parties cannot be presumed to have relied on the place where the conduct occurred, the traditional territorial approach continues to be applied in most U.S. courts. The justification for continuing to use this somewhat antiqued approach is that it creates certainty as to the status of the family - a social necessity. ${ }^{97}$

At least one state, Texas, seems to have departed from the traditional approach. In Seth v. Seth, ${ }^{98}$ the court applied the "new learning" and concluded that under Texas law, the place of the couple's domicile, rather than the law of the place where the divorce occurred, should apply.

The facts, accepted by the appellate court, were as follows: ${ }^{99}$ On June 6, 1957, Husband and Wife One were married in India. In 1966, Husband began cohabiting with Wife Two. ${ }^{100}$ Shortly thereafter, Husband was granted permanent resident alien status in the United States. Approximately eight years later, on June 17, 1975, the Husband and Wife Two converted to Islam and were married in Bombay, India, in an Islamic ceremony. ${ }^{101}$ Over a year later, on November 21, 1976, Husband pronounced a talāq divorce from Wife One in Kuwait. ${ }^{102}$ Wife One

97 Without such a rule, a couple might be considered married in some state and not other.

$98 \quad 694$ S.W.2d 459 (Tex. App. Fort Worth 1985).

The three main parties involved were: Mohan Seth ("Husband”); Saroj Seth ("Wife One"); and Anuradha Mohan Seth ("Wife Two").

$100 \quad$ The trial court had also found that Husband and Wife Two were married in Bombay, India, on or about June 17, 1975. The appellate court seemed to conveniently ignore that fact. The validity of the second marriage does not seem to have been disputed since it, apparently, was valid under Indian law.

102 There was some dispute as to whether the tala q divorce would be valid under Islamic law. Wife Two's experts testified to the effect that a purported conversion by a man to Islam for the sole purpose of divorcing his wife through talāq, and the talāq itself, are not subject to any attack whatsoever on the grounds that they were simply sham ceremonies. According to this view, Islamic law recognizes and validates any conversion and subsequent talāq so long as certain formalities are complied with, regardless of the man's underlying intentions and motives. Wife One's expert, on the other hand, stated 
was not notified of this procedure. The day after the divorce, Husband and Wife Two were married again in another Muslim ceremony. On March 8, 1977, Wife Two was granted permanent resident alien status in the U.S. as the wife of a husband, who had already been granted resident alien status. They continued to live together in Texas until Wife Two filed for divorce in a Texas court and sought a division of the property. Wife One intervened, alleging that she was the lawful wife of Husband and that Wife Two was never lawfully married to Husband had no right to Husband's property.

While acknowledging that courts have traditionally chosen and used the law of the place a divorce or marriage purportedly occurs to determine the validity of the ceremony, the court noted that several recent decisions by the Supreme Court of Texas indicated that choice-of-law decisions should not be made on the basis of the mechanical test of where the act occurred (lex loci) but should instead be made on the basis of the most significant relationship approach, using the factors set forth in the Restatement (Second) of Conflict of Laws $\S 6$ (1971). ${ }^{103}$ Therefore, the court concluded that the Restatement criteria, and not the place of celebration test, should be applied to determine choice of law in a marriage or divorce context.

that under Islamic law, conversion accomplished for the purpose of circumventing the law will not be enforced. That expert went on to say that, in his opinion, the alleged divorce between Husband and Wife One, procured through talāq, would be invalid. The court did not find it necessary to resolve this conflict.

Choice-of-Law Principles:

(1) A court, subject to constitutional restrictions, will follow a statutory directive of its own state on choice of law.

(2) When there is no such directive, the factors relevant to the choice of the applicable rule of law include

(a) the needs of the interstate and international systems,

(b) the relevant policies of the forum,

(c) the relevant policies of other interested states and the relative interests of those states in the determination of the particular issue,

(d) the protection of justified expectations,

(e) the basic policies underlying the particular field of law,

(f) certainty, predictability and uniformity of result, and

(g) ease in the determination and application of the law to be applied. 
The court concluded that the most important factor to be considered under the Restatement Second was factor (b): the relevant policies of the forum, notwithstanding that "the critical events" did not occur in Texas and that at the time of the events, the parties themselves had no apparent connection with Texas, and that even at the time of trial, Husband and Wife Two were citizens of India and not the U.S. The court emphasized that Texas's interest in this suit resulted from the fact that Husband and Wife Two lived in Texas since 1977, during which time they acquired real property within the State.

The court then made a critical assumption: Based on the testimony of Wife Two's experts, the trial court could have found that Islamic law simply allows a non-Muslim man to convert to Islam by pronouncing a short phrase, and then divorce his wife through the ex parte procedure of talāq. The court then held that "The harshness of such a result to the non-Muslim divorced wife runs so counter to our notions of good morals and natural justice that we hold that Islamic law in this situation need not be applied." 104 Thus, the appellate court adopted the lower court's decision that:

The marriage between Husband and Wife One was a valid marriage which had never been dissolved in any manner subject to recognition by the trial court; that the alleged marriage of Husband and Wife Two in Bombay, India, on or about June 17, 1975, was void as a matter of law; and further that the alleged marriage of Husband and Wife Two in the Republic of Kuwait on or about November 22, 1976, was void as a matter of law. ${ }^{105}$

There is no indication why the appellate court did not consider the validity of Husband's first marriage to Wife Two, since it was apparently valid in India where it was performed. The result in this family dispute could have been that the Husband was married to Wife One only (the result in this case), that Husband was married to both

104 The court distinguished Chaudry v. Chaudry, 388 A.2d 1000, 1005 (App. Div. 1978), where the talāq divorce was confirmed by a Pakistani court after it had been contested by the wife.

$105 \quad 694$ S.W. 2d at 461. 
Wife One and Wife Two (if the Bombay marriage is recognized, but the Kuwait divorce is not) or that Husband was married to Wife Two only (if both the Bombay marriage and the Kuwait divorce are recognized). Fortunately, there were no children from the marriage and the need to determine issues of legitimacy did not arise.

\section{U.S. RECOGNITION OF TALĀQ DIVORCES}

There are a number of reported court decisions dealing with talāq divorces. The results are not always consistent, but the following two cases highlight important factual differences which might explain some of the apparent inconsistencies. ${ }^{106}$

Chaudry v. Chaudry ${ }^{107}$ recognized the validity of taläq divorces and the application of foreign law to determine the divorced spouse's right to share in her husband's economic wealth.

The parties (husband and wife) were both citizens of Pakistan. The wife and their children resided in Pakistan; the husband resided in New Jersey where he practiced medicine as a psychiatrist. ${ }^{108}$

$106 \quad$ To the extent the inconsistencies reflect basic differences in the application of generally accepted principles of American law, they may well reflect the fact that recognition of foreign marriages and divorces is governed by state rather than national law and such disputes are decided by state courts. 388 A.2d 1000 (App. Div. 1978).

108 After they were married, they resided in Pakistan for about a year during which time their first child was born. The husband went to England, where his wife and child eventually joined him. They stayed in England for about seven months before coming to the United States. They lived in Connecticut for three years and their second child was born there. They then moved to New Jersey where the husband obtained a job with the Trenton Psychiatric Hospital. Two years later, the wife and two children returned to Pakistan, with, according to the husband, the permanent intention to remain there. (She claims he told her he would return permanently to Pakistan to join them once he had completed his state medical examination, since his visa was then expiring). He did return to Pakistan in October 1970 to a position and remained there. He remained with his wife and children until February 1971, when the Trenton Psychiatric Hospital sent him papers permitting 
The wife filed suit in a New Jersey court alleging "a subsisting marriage," unjustifiable abandonment by the husband, and his failure to adequately support her and their children. She sought separate maintenance and support for the children or, in the event the court found that her husband had lawfully divorced her, alimony, equitable distribution of her husband's assets and child support. ${ }^{109}$

The husband countered that he had previously obtained a valid divorce in accordance with the laws of Pakistan, which had been confirmed by a Pakistani court, and that he had met all financial obligations to the wife in accordance with the antenuptial agreement (the marriage contract) between them, as well as under the laws of Pakistan.

The trial judge refused to recognize the Pakistan divorce under principles of comity and awarded the wife separate maintenance in the sum of $\$ 430$ a month. The court held that the husband's method of obtaining the divorce in the Pakistan consulate in New York, while he resided in New Jersey, rendered it invalid under the laws of New Jersey. The trial court apparently also concluded that Pakistan law, under which a divorced wife is not entitled to alimony, and the antenuptial agreement, under which the wife would only receive approximately $\$ 1,500$ from the husband, were so offensive to the State's public policy as to invalidate the divorce. ${ }^{110}$

The Court of Appeals reversed, holding that (1) the trial judge erred in refusing to recognize the Pakistani divorce as valid under principles of comity and, accordingly, should not have awarded the wife separate maintenance; and (2) the wife was not entitled to equitable distribution or alimony. ${ }^{111}$

The Pakistani divorce proceedings: On December 16, 1973 the husband advised his wife that he had filed divorce papers with the

him to enter the United States. He returned to Pakistan in April 1972 for about four weeks, during which time he lived with his wife. He then returned to New Jersey without his family. The parties' third child was born in Pakistan in January 1973. He did not return to the U.S. until December 29, 1975, after he had obtained a Pakistan divorce.

$109 \quad$ Ibid, at 1002.

110 Although the trial court's judgment awarded separate maintenance to the wife, it denied support for the three children, predicated on the court's asserted lack of authority over support for children beyond its jurisdiction.

$111 \quad$ Ibid, at 1003. 
Pakistan consulate in New York City. (The Pakistan appellate court found that the wife had received this letter). He also sent her a copy of the talāq after it was effected at the Pakistan consulate in New York. The divorce was confirmed by the Pakistan lower court on November 5, 1974.

The wife then petitioned the appellate court, contending that for various reasons the divorce was invalid. The validity of the divorce was upheld, after a hearing by the Pakistan appellate court, in a written opinion dated December 30, 1975. The wife was represented by counsel in both Pakistan courts. The time for appeal to the highest court of Pakistan passed and the judgment of the appellate court validating the divorce became final.

The Court of Appeals distinguished this case from those where was there was nothing more than the mere declaration of divorce talāq before the Pakistan consulate. ${ }^{112}$ As the court pointed out, unlike a typical "bare taläq" where the wife does not appear in person or by counsel, this was actually confirmed by a court in Pakistan after being contested by the wife; and thereafter, after an appeal by the wife in a further contested proceeding, the Pakistan appellate court held the divorce to be valid. Thus, the court concluded that "under these circumstances," principles of comity require that the divorce be recognized and the status of the parties as being divorced should have been acknowledged by the trial judge. ${ }^{113}$

The Marriage Contract or Nikahnama: ${ }^{114}$ The court then turned to the wife's alternative claim for alimony, equitable distribution of her husband's assets and child support, a claim which the trial court did not reach since it refused to recognize the Pakistan divorce.

The court found that in 1958, by negotiation between their parents, a marriage contract between the husband and wife was entered into; at that time and when they were married some three years later, they were both citizens of Pakistan. ${ }^{115}$

The evidence established that the antenuptial agreement provided that the wife, at any time during or after the marriage, on demand could

\footnotetext{
112 Compare, Shikoh v. Murff, 257 F.2d 306 (1958).

113 Chaudry v. Chaudry, 388 A.2d 1000, 1003 (App. Div. 1978).

114 Perhaps foretelling in eventual approval, the court referred to it as "the antenuptial agreement."

115 Ibid.
} 
obtain from her husband 15,000 rupees, about $\$ 1,500$. Although such agreement could have provided that she have additional rights in her husband's property, this one contained no such provision. Under Pakistani law she was not entitled to alimony or support upon a divorce. Indeed, the court found that a provision in the agreement to the contrary would be void as a matter of law. ${ }^{116}$

Thus, the wife could prevail only if the court refused to apply Pakistan law and substituted New Jersey law. The court declined to preclude such an outcome in other cases:

For the purpose of this opinion, we assume, without deciding, that where there is a sufficiently strong nexus between the marriage and this State e.g., where the parties have lived here for a substantial period of time a claim for alimony and equitable distribution may properly be considered, in the court's discretion, after a judgment of divorce elsewhere, under [New Jersey law] even though such relief could not have been obtained in the state or country granting the divorce. ${ }^{117}$

But it could not find "an adequate nexus of the marriage to this State" to justify an award to the wife of alimony or equitable distribution under New Jersey law, holding such a relationship was not established merely because the wife and children resided here from 1966 to 1968, even though, as the trial judge found, it was the husband's conduct that prevented the wife from returning to this State after 1968. ${ }^{118}$ Thus, the court held: "Under these circumstances the denial of alimony or equitable distribution to the wife cannot be said to offend our public policy."119

A similar issue was presented in Aleem v. Aleem ${ }^{120}$ but the facts were significantly different - and so was the result. ${ }^{121}$ The issue, again,

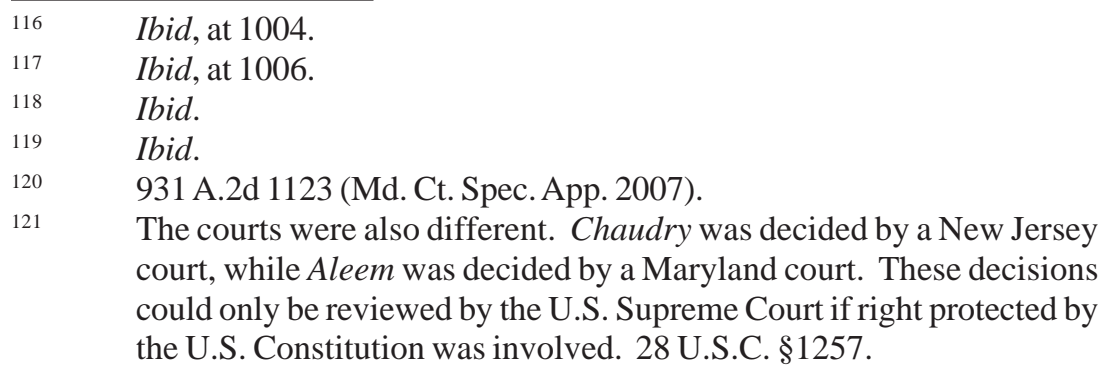
court, while Aleem was decided by a Maryland court. These decisions could only be reviewed by the U.S. Supreme Court if right protected by the U.S. Constitution was involved. 28 U.S.C. §1257. 
was whether comity should be given to a talāq divorce obtained by the husband based on Pakistani law after his wife had sued him for divorce in a Maryland court ${ }^{122}$ and, if so, to what extent, if any, should it affect her property right in his assets, namely, his pension. ${ }^{123}$ Because the

122 Four months after the divorce action was filed in the state court in Maryland, the husband went to the Pakistani Embassy in Washington, D.C. and there, before two witnesses, he signed and had notarized a "Divorce Deed," which in relevant part reads:

"Now this deed witnesses that I the said Irfan Aleem, do hereby divorce Farah Aleem, daughter of Mahmood Mirza, by pronouncing upon her Divorce/Talāq three times irrevocably and by severing all connections of husband and wife with her forever and for good.

"1. I Divorce thee Farah Aleem.

"2. I Divorce thee Farah Aleem.

"3. I Divorce thee Farah Aleem."

With respect to property disposition on divorce under Pakistani law, that expert witness tendered by Husband would have opined:

"Under Pakistan law, a division of the properties, consequent upon termination of the marriage, takes place ipso facto upon such termination in the following manner:

a) All property owned by the husband on the date of such termination of marriage remains the husband's property and the wife has [no] claim thereto.

b) All property owned by the wife on the date of termination of the marriage remains the wife's property and the husband has no claim thereto."

The husband also submitted the affidavit of a Pakistani attorney, whom Husband tendered as an expert.

That affidavit identified the marriage contract between the parties as a Nikahnama. He said that it is "ordinarily executed in a standardized form," and that "[t]he terms of the contract are supplied by operation of Pakistani laws which govern the Nikahnama and the marriage." He enumerated the remedies available to a wife in divorce under Pakistan law, and he opined that a wife cannot make a claim to "[m]oney, property or assets titled in the name of the husband on the date of the divorcethese remain the property of the husband and the wife has no claim to them except her claim to the amount/property/assets mentioned in the contract[.]" Because the pension is an asset of the pensioner, a wife does not have any right to a husband's pension, "in whole or in part," unless the Nikahnama expressly provides for it. The appellate court accepted those tenders as accurate statements of Pakistani law. 
husband and wife, although nationals of Pakistan, had resided in Maryland for more than 20 years, ${ }^{124}$ the court applied Maryland not Pakistani law.

The trial judge summarily rejected the husband's motion to dismiss the Maryland divorce proceeding on the basis of his Pakistani talāq divorce:

The idea that in this case Mr. Aleem can apply for and on the basis of his declaration receive a divorce [under Islamic law] offends the notions of this Court in terms of how a divorce is granted. I am not, as a member of this bench, going to give comity to such an award. ${ }^{125}$

The Court of Appeals took a rather different approach indentifying two basic issues to be resolved: (1) whether the Maryland count had the judicial authority (jurisdiction) to hear and resolve the dispute between two Pakistani nationals and, (b), if so, what law should it apply to determine Mrs. Aleem's claim to a share of her husband's pension.

The first issue was easily resolved:

It is clear that this State has a sufficient nexus with the marriage to effect an equitable distribution of marital property. The parties resided in Maryland for over twenty years. Their children were born and raised here. In addition, Wife, who seeks the equitable relief, is now a permanent resident of the United States, in Maryland. ${ }^{126}$

The court's resolution of the second issue seemed to involve two issues: (1) whether the legal effect of the talāq - which the court seems to have accepted as terminating the marriage - reached property

The parties were married in Karachi in 1980 (she was 18 and he was 29 and a student at Oxford). A few weeks later, he moved to England where she eventually joined him. When he completed his studies, the parties moved to the United States. They had two children; both were born in the United States and were U.S. citizens.

125 Ibid, at 1127.

$126 \quad$ Ibid, at 1132. 
not located in Pakistan (i.e., the husband's pension) and, if not, (2) whether Pakistani law or Maryland law be used to determine her right to a share in the pension.

The first issue in the court's view turned on whether the Pakistani divorce was ex parte or inter parte, i.e. whether Mrs. Aleem was a party to the divorce proceeding. While she did not participate personally or through counsel, her counsel did send a letter on her behalf to the Cantonment Board Clifton, which might have been considered a "general appearance" which would have conferred "personal jurisdiction on that Board over the person of the Wife." But the court concluded that it was not: "The letter was a courteously phrased objection to jurisdiction, in the nature of a special appearance." 127

The presence of only one spouse in the jurisdiction coupled with the absence of personal jurisdiction over the absent spouse, creates what is known in the United States as a "divisible divorce" - a situation where a court having the authority to dissolve the marriage does not have authority to affect the non-appearing spouse's property rights. ${ }^{128}$

Thus, the court found it "unnecessary" to decide whether Maryland would recognize the Pakistani divorce, as a divorce, ${ }^{129}$ but held that, as to the Maryland property - the husband's pension - the Pakistani divorce "does not require enforcement by comity." 130

But an issue remained: assuming that the Maryland court has the authority to resolve the dispute over the pension and need not "enforce" the Pakistani divorce decree to the extent that if affect such property,

127 A "special appearance" allows a party to appear before a court to challenge the court's jurisdiction without the appearance being viewed as consent to jurisdiction.

128 In Estin v. Estin, 334 U.S. 541 (1948), the Supreme Court decided that a Nevada court had no power to terminate the obligations of the husband to pay support pursuant to a pre-nuptial agreement made in New York, because the Nevada court had acquired no personal jurisdiction over the wife.

129 The court noted that: "In the instant matter, neither party objects to dissolution of their former marital status. The answer to the question of whether Pakistani law applies affects only enforcement of the Pakistani divorce on property rights under Maryland law.” Aleem v. Aleem, 931 A.2d 1123, 1132 (Md. Ct. Spec. App. 2007).

$130 \quad$ Ibid. 
what law - the law of Pakistan or the law of Maryland - should be used to determine the respective rights to the property.

First, the court found that the customary Pakistani marriage contract signed by both parties could not "be equated with a premarital or post-marital agreement that validly relinquished, under Maryland law, rights in marital property.” Having concluded that the Pakistani marriage contract was "silent" on this question, it faced a not atypical choice of law issue: Pakistani law does not recognize marital property, but such rights are recognized by Maryland law. "In other words, the 'default' under Pakistani law is that Wife has no rights to property titled in Husband's name, while the 'default' under Maryland law is that the wife has marital property rights in property titled in the husband's name." The court found this conflict "so substantial that applying Pakistani law in the instant matter would be contrary to Maryland public policy" and applied Maryland law giving the wife an interest in her husband's pension.

\section{CONCLUSION}

Although no reliable data is available, it has been reported that there may be as many as 20,000 American Muslim polygamists in the United States, principally in New York, New Jersey and Pennsylvania. ${ }^{131}$ Most are African-American Muslims or recent immigrants from West Africa. ${ }^{132}$ Notwithstanding this not insignificant presence of polygamous Muslim families in the United States, prosecutions of polygamy involving Muslim Americans are almost non-existent. When they do occur, there generally are additional factors justifying the prosecutions. For example, a Muslim American polygamist was recently sentenced for his torture of three wives and children, not for his plural marriage. ${ }^{133}$ Polygamy among recent immigrants is undoubtedly kept secret because it could subject

$131 \quad$ Useem, Andrea, What to Expect When You're Expecting a Co-Wife, Why American Muslims Don't Care to Legalize Polygamy, Slate, FaithBased: Religion, Spirituality, and Sacrilege, July 24, 2007, available at http://www.slate.com/id/2170977/ (last visited April 3, 2009.)

132 Bernstein, Nina, In Secret, Polygamy Follows Africans to N.Y., The New York Times, March 23, 2007.

133 McCoy, Tina, Man with three wives, 19 children convicted of torture and abuse, The Press Enterprise, June 11, 2008. 
the immigrant to removal or be grounds for denying permanent resident or citizen status.

This may explain why there is a scarcity of reported U.S. court decisions dealing with the recognition of marriages and divorces valid under Islamic law. Few, if any, cases directly invoke the First Amendment to support a contention that it supports an Islamic man's right to have more that one wife or his right to a unilateral talāq divorce.

Although the supporters of gay marriage vociferously asserted that recognition of monogamous marriage between persons of the same gender does not automatically lead to the recognition of polygamous marriages, ${ }^{134}$ it seems difficult to explain why laws banning the former are unconstitutional while laws banning the latter are not. But the road to the full recognition of Islamic marriages will not be an easy one as it will require the U.S. Supreme Court to overrule or somehow distinguish Reynolds v. United States, something it has shown no interest in doing. Recognition of "bare taläq" is even more problematic as it raises both policy and constitutional concerns. Although it is relatively easy to obtain a divorce in the United States, the fundamental policy is still to make every effort to encourage the parties to participate in some form of mediation or conciliation in an attempt to keep the couple together. As a policy matter, talāq may be viewed as making the termination of a marriage far too easy. ${ }^{135}$ But the biggest obstacle to recognition of taläq divorces - potentially a constitutional one is that it is historically only available to the husband - not the wife. ${ }^{136}$ It seems inevitable that there will be more litigation on these issues in the relatively near future.

\footnotetext{
$134 \quad$ They were forced to take that position as the opponents to gay marriage argued that allowing gay marriage would lead to the recognition of polygamous and incestuous marriages. [An approach often referred to as a "slippery slope" argument].

135 Most states now grant "no fault" divorces based on "irreconcilable differences," which, like Talāq, may only represent the wishes of one of the spouses.

136 As mentioned below, no-fault proceedings can be - and often are brought by the spouse.
} 